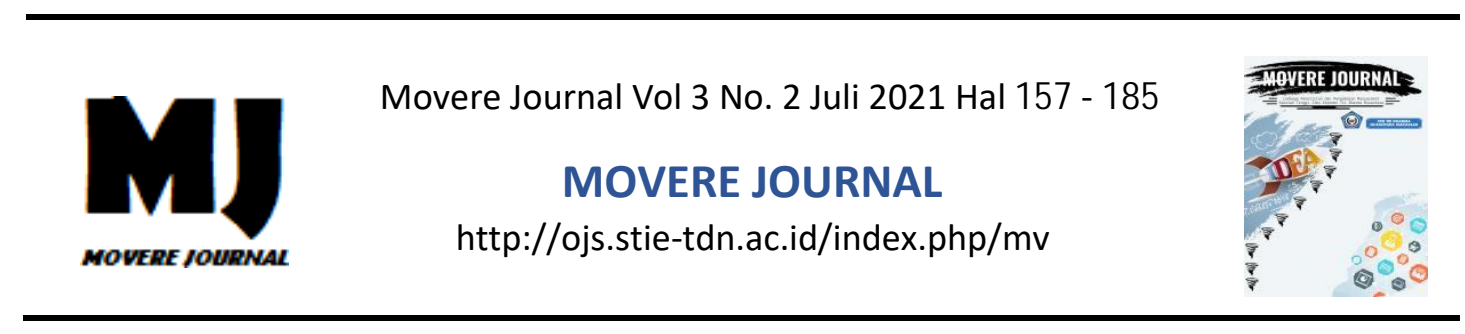

\title{
Pengaruh Harga Terhadap Keputusan Pembelian Air Mineral Privat Label Indomaret Cabang Pacerakkang Daya
}

\author{
Taufik $^{1}$, A. Tendean ${ }^{2}$
}

Sekolah Tinggi Ilmu Ekonomi Tri Dharma Nusantara ${ }^{1}$

Sekolah Tinggi Ilmu Ekonomi Tri Dharma Nusantara ${ }^{2}$

\author{
Email : taufikmuhammad672@gmail.com ${ }^{1}$ \\ aanditendean@gmail.com $^{2}$
}

\begin{abstract}
Abstrak : Penelitian ini bertujuan untuk mengetahui pengaruh harga terhadap keputusan pembelian. Adapun jenis data yang digunakan adalah data kualitatif dan kuantitatif kemudian sumber data yang digunakan yaitu data primer dan sekunder dengan responden sebanyak 63 orang. Data-data yang terkumpul dianalisis secara deskriptif artinya data yang diperoleh di lapangan, diolah sedemikian rupa sehingga memberikan pemahaman yang sistematis. Selanjutnya diadakan presentase skor aktual variabel harga dan variabel keputusan pembelian lalu perhitungan statistik dengan pendekatan analisis regresi sederhana, koefisien korelasi, koefisien determinasi $(R)$ dan uji-t. Dari perhitungan regresi didapatkan nilai sebesar $\mathrm{Y}=31,9+0,24 \mathrm{X}$, sedangkan nilai koefisien korelasi (r) sebesar 0,88 , dan koefisien determinasi $(R)$ sebesar 0,7744 (77,44\%). Hasil perhitungan uji-t dimana $\mathrm{t}_{\text {-hitung }}>\mathrm{t}_{\text {t } \text { tabel }}$ yaitu 14,47 $>1,67$ hal ini menyatakan dan menjelaskan bahwa ada pengaruh yang signifikan antara variabel harga terhadap variabel keputusan pembelian Air mineral privat label pada toko Indomaret cabang Pacerakkang Daya.
\end{abstract}

Kata kunci: Harga, keputusan pembelian.

\begin{abstract}
This study aims to determine the effect of price on purchasing decisions. The types of data used are qualitative and quantitative data and then the data sources used are primary and secondary data with 63 respondents. The data collected were analyzed descriptively means that the data obtained in the field were processed in such way to provide a systematic understanding. Furthermore, the percentage of the actual score of the price variable and the purchasing decision variable is then carried out by statistical calculations using a simple regression analysis approach, correlation coefficient, determination coefficient $(R)$ and t-test. From the regression calculation obtained the value of $Y=31.9+0.24 X$, while the value of the correlation coefficient $(r)$ is 0.88 , and the determination coefficient $(R)$ is $0.7744(77.44 \%)$. The results of the t-test calculation where $t_{\text {-count }}>t$-table is $14.47>1.67$. It states and explains that there is a significant influence between the price variables on the purchasing decision variables of mineral water private label at the Indomaret store on Paccerakkang Daya Branch.
\end{abstract}


Keywords: Price, purchase decision

\section{PENDAHULUAN}

\section{A. Latar Belakang}

Era revolusi industri 4.0 dimana kehadiran teknologi berbasis internet semakin memberikan kontribusi terhadap perekonomian. Kehadiran tersebut kemudian memberikan sebuah tantangan baru bagi perusahaan berbasis offline untuk menghadirkan produk sesuai dengan kebutuhan konsumen.

Tantangan industri retail yang terjadi secara terus menerus membuat pegiatnya harus bekerja ekstra keras demi mempertahankan eksistensi. Hal ini tidak berarti industri retail punah. Namun perkembangan teknologi dan semua kemudahan yang ada secara perlahan-lahan menekan keberadaan toko-toko mereka.

Tantangan ini begitu berat bagi mereka karena ada banyak perusahaan retail yang melakukan penutup toko-toko mereka. Sebut saja Giant, lotus, dan 7-Eleven. Dengan hadirnya toko-toko online itu, hal tersebut semakin membuat konsumen semakin selektif dalam menetapkan keputusan pembeliannya, selain toko online pesaing toko-toko offline juga adalah saingan yang tidak boleh dianggap remeh. Dalam bauran pemasaran seperti produk, harga, promosi, dan tempat mengharuskan perusahaan memaksimalkan strateginya dengan situasi persaingan yang ada. Harga sebagai salah satu bagian dari marketing mix juga menjadi salah satu faktor yang menentukan laba bagi perusahaan. Harga menurut Tatik Suryani (2017 : 138) "Pada umumnya, Harga diartikan sebagai sejumlah uang yang dibayarkan oleh konsumen untuk memperoleh produk yang diinginkan".

Perusahaan dalam menyediakan produk yang berkualitas dan berdaya saing maka diperlukan harga yang mudah dijangkau oleh konsumen. Penetapan harga yang sesuai dengan kemampuan atau daya beli konsumen sangat mempengaruhi persaingan dan transaksi pembelian konsumen. banyaknya pilihan produk yang tersedia membuat konsumen lebih selektif dan benar-benar melakukan evaluasi dalam melakukan keputusan pembelian.

Sedangkan menurut Schiffman dan Kanuk (2000) dalam Sangaji dan Sopiah (2013 : 120) "Keputusan sebagai pemilihan suatu tindakan dari dua pilihan alternatif atau lebih".Dari penjelasan tersebut dapat disimpulkan bahwa harga menjadi bagian penting dalam pengambilan keputusan konsumen.

Indomaret sebagai salah satu toko reatail yang berkembang pesat di Indonesia yang menawarkan berbagai macam kebutuhan, baik seperti makanan, minuman, alat kecantikan, tiket pesawat, baya cicilan, dan alat-alat rumah tangga lainnya. Seperti kita ketahui bersama menjamurnya toko-toko retail modern membuat semua perusahaan 
lebih memperhatikan kosumennya guna menambah omset perusahaan. Tidak terkecuali indomaret grup yang kita ketahui bersama setiap ada gerai indomaret maka bisa dipastikan ada rivalnya Alfa midi grup maupun Alfamart grup. Hal ini membuat persaingan ketiga toko retail tersebut semakin ketat. Salah satu langkah yang diambil Indomaret grup agar mudah di ingat oleh konsumen adalah dengan menghadirkan produk privat label baik itu minuman, makanan,alat kecantikan dan alat-alat rumah tangga.

Mayoritas gerai Indomaret berada di tempat-tempat yang strategis maka wajar saja jika penjulan produk air mineral yang dijual laku keras di banding dengan produk lainnya. karena penjualan air mineral lumayan banyak maka perusahaan menciptakan produk privat label air mineral guna agar pelanggan mudah mengingat brand indomaret. Selain itu perusahaan mencoba menciptakan suasana lebih menarik dan nyaman.

Karena banyaknya produk air mineral yang dijual dan dipajang di rak minuman serta beragamnya harga, kualitas dan jenis kemasan maka konsumen akan lebih selektif dalam melakukan keputusan pembelian.
Banyaknya air mineral yang sudah menguasai konsumen produk air mineral seperti aqua, lemineral, club, ades membuat perusahaan harus dapat menjadikan produk privat label juga dapat bersaing dengan produk yang lain. Dengan melihat situasi produk dengan berbagai macam variasi strategi harga yang digunakan untuk memikat konsumen, maka perlu strategi harga produk air mineral indomaret Privat label agar bisa bersaing dengan produk yang lain. Melihat situasi dan kondisi tersebut penulis tertarik melakukan penelitian dengan judul pengaruh harga terhadap keputusan pembelian produk privat label Indomaret pada Indomaret cabang Pacerakkang Daya di Makassar?

\section{B. Rumusan Masalah}

Berdasarkan latar belakang di atas maka dirumuskan permasalahan sebagai berikut "Apakah harga berpengaruh terhadap keputusan pembelian air mineral privat label pada Indomaret cabang Pacerakkang Daya di Makassar?".

C. Tujuan dan Manfaat Penelitian

1. Tujuan Penelitian

Berdasarkan latar belakang dan rumusan masalah yang ada, maka penelitian ini dilakukan dengan tujuan untuk mengetahui pengaruh 
harga terhadap keputusan pembelian konsumen pada Indomaret cabang Pacerakkang Daya di Makassar?

2. Manfaat Penelitian

Penelitian ini diharapkan berguna untuk banyak orang dan hal yang ingin dicapai adalah:

a. Bagi peneliti, untuk menambah dan mengembangkan wawasan pengetahuan peneliti khususnya mengenai pengaruh strategi harga terhadap keputusan pembelian.

b. Bagi perusahaan, untuk dijadikan sumber pengetahuan dalam pengambilan keputusan penetapan harga.

c. Bagi peneliti selanjutnya, hasil penelitian diharapkan dapat menjadi bahan referensi untuk penelitian selanjutnya pada bidang manajemen

\section{TINJAUAN PUSTAKA}

\section{A. Pengertian Harga}

Harga didefinisikan sebagai jumlah yang dibayarkan oleh pembeli. Harga merupakan suatu cara bagi seorang penjual untuk membedakan penawarannya dari para pesaing. Dalam suatu produk terkandung nilai ekonomis yang pada umumnya disebut harga. Berikut definisi harga menurut beberapa para ahli.

$$
\text { Menurut Alma (2018:171), }
$$
"Harga (price) adalah nilai suatu barang yang dinyatakan dengan uang. Harga mempunyai hubungan dengan pengertian nilai dan keguanaan". Nilai adalah ukuran jumlah yang diberikan oleh suatu produk apabila produk itu, ditukarkan dengan produk lain. Sedangkan kegunaan adalah atribut dari sebuah item yang memberikan tingkat kepuasan tertentu kepada konsumen.

Sedangkan menurut Kotler dan Keller (2009:76), "Harga adalah salah satu elemen bauran pemasaran yang menghasilkan pendapatan; elemen lain menghasilkan biaya”. Mungkin harga adalah elemen termudah dalam program pemasaran untuk disesuaikan; fitur produk, saluran dan bahkan komunikasi membutuhkan lebih banyak waktu.

Harga sebagai sejumlah uang yang harus dibayar untuk mendapatkan hak pengunaan produk. Pemahaman konsumen terhadap harga mempunyai dampak yang penting terhadap penetapan kebijakan harga. Sedangkan menurut Tjiptono dan Anastasia Diana (2016:218), "Harga merupakan satuan monoter atau ukuran lainnya (termasuk barang dan jasa lainnya) yang ditukarkan agar memperoleh hak kepemilikan atau pengunaan suatu barang atau jasa".

Dari berbagai pendapat di atas dapat disimpulkan bahwa harga merupakan suatu nilai tukar yang bisa disamakan dengan uang atau barang lain untuk manfaat yang diperoleh dari suatu barang atau jasa bagi seseorang atau kelompok pada waktu tertentu dan tempat tertentu. Istilah harga digunakan untuk memberikan nilai finansial pada barang atau jasa. Harga juga sebagai nilai suatu produk atas manfaat yang

Corresponding Author: Taufik

(C) 2021 STIE TDN. All rights reserved 
dirasakan.

\section{B. Kebijakan Harga Retailer}

Kebijakan harga retailer umumnya adalah penetapan harga yang murah agar memperoleh reputasi sebagai toko termurah. Adapun menurut Alma (2018:175), ada beberapa macam price policy yang dilakukan oleh retailer yaitu sebagai berikut:

1. Margin price

Marging pricing adalah penentuan harga jual yang dikehendaki tergantung kepada biaya-biaya yang telah dikeluarkan, lambat atau cepatnya peredaran barang, tingkat bunga yang berlaku resiko kerusakan dan perkembangan harga.

2. Pricing lining

Policy harga di sini ialah menggolongkan barang-barang yang berharga satuan Rp. 10.000,00 Rp. $20.000,00$ Rp. $30.000,00$ dan seterusnya. Tentu saja harga yang digolong-golongkan itu beberapa barang mungkin kemahalan, dan untuk beberapa barang lain kemurahan.

\section{Competitor prices}

Untuk memperoleh reputasi sebagi toko yang murah untuk barangbarang yang dikenal oleh umum ( mengikuti price leader atau loss leader). Loss leader artinya harganya ditetapkan di bawah harga umum.

\section{Discount house}

Discount house adalah suatu toko eceran yang menjual barangbarang dari merek yang terkenal, dengan suatu potongan harga yang menarik, sehingga harga sesungguhnya lebih rendah dari harga umum.biasanya potongan harga yang dilakukan perusahaan - perusahaan go internasional.

\section{Judgement pricing}

Dasar penetapan harga ini berdasarkan atas kira-kira saja. Misalnya disebabkan karena model atau kejarangan barang tersebut.

6. Customary prices

Apabila tiba-tiba harga bahan baku meninglkat maka perusahaan tidak melakukan tindakan menaikkan harga barangnya, sebab produsen ingin tetap menjaga hubungan dengan produsen. Jika bahan baku melonjak maka perusahaan tidak akan mengubah harga jual tetapi mengurangi jumlah isi, mengurangi berat timbangan dan menurunkan kualitas barang misalnya kurangi pemakaian gula, coklat dan sebagaianya.

\section{Odd prices}

Price policy memasang harga seperti Rp. 2.975 untuk harga yang seharusnya Rp. 3.000. dengan harga tersebut secara psikologis konsumen merasa memperoleh untung besar, membayar Rp. 2.975 daripada membayar Rp. 3.000.

\section{Combinations offers}

Sering kita lihat di pasar orang sering menjual sisi diikat dengan minyak rambut + cermin harga $\mathrm{Rp}$. 15.000. ini lah yang disebut dengan combinations offers. Maksudnya disamping memikat calon pembeli juga

Corresponding Author: Taufik

C 2021 STIE TDN. All rights reserved 
melariskan barang lain yang keadaan pasarnya lagi sepi. Cara ini sering dilakukan seiring dengan situasi pasar yang sedang lesu, agar produk bisa cepat laris dan perputaran produksi tetap berjalan.

\section{Indikator Harga}

Indikator harga adalah ciri harga yang telah ditetapakan oleh perusahaan yang mempertimbangkan beberapa unsur keterjangkauan harga, daya saing, kualitas serta manfaat.

Menurut Kotler dan Amstrong (2012:314), menjelaskan ada empat ukuran yang mencirikan harga yaitu:

1. Keterjangkauan harga

Konsumen bisa menjangkau harga yang telah ditetapkan oleh perusahaan. Produk biasanya ada beberapa jenis dalam satu merek dan harganya juga berbeda dari termurah sampai termahal

2. Harga sesuai kemampuan atau daya saing harga

Konsumen sering membandingkan harga suatu produk dengan produk lainnya. Dalam hal ini mahal murahnya harga suatu produk sangat dipertimbangkan oleh konsumen pada saat akan membeli produk tersebut. Itu salah satunya disebabkan tingkat atau daya beli konsumen dengan pendapatannya.

3. Kesesuaian harga dengan kualitas produk

Harga sering dijadikan indikator kualitas bagi konsumen. Orang sering memilih harga yang lebih tinggi diantar dua barang karena mereka melihat adanya perbedaa kualitas. Apabila harga lebih tinggi, orang cenderung beranggapan bahwa kualitasya juga lebih baik. Begiotuoun sebaliknya, jika harga lebih rendah, orang cenderung beranggapan bahwa kualitas barang tersebut juga kurang baik.

4. Kesesuaian harga dengan manfaat

Konsumen memutuskan

membeli suatu produk jika manfaat yang dirasakan lebih besar atau sama dengan yang dikeluarkan untuk mendapatkannya. Jika konsumen merasakan manfaat yang lebih kecil dari uang yang dikeluarkan maka konsumen akan beranggapan bahwa produk tersebut mahal dan konsumen akan berpikir dua kali untuk melakyukan pembelian ulang.

\section{Pengertian Keputusan Pembelian}

Setiap konsumen sebelum melakukan transaksi maka akan melakukan pengambilan keputusan untuk memilih dan menggunakan produk sesuai dengan keiginannya. Keputusan pembelian merupakan tahapan terakhir sebelum melakukan pembelian suatu produk.

Menurut Kotler dan Keller (2007:223), “Keputusan pembelian merupakan tahapan yang dilakukan oleh konsumen sebelum melakukan keputusan pembelian suatu produk". Pemenuhan kebutuhan ini terkait dengan beberapa alternatif sehingga 
perlu dilakukan evaluasi yang bertujuan untuk memperoleh alternatif-alternatif yang terbaik.

Menurut Schiffman dan Kanuk (2000) dalam Sangadji dan Sopiah (2013:120), "Mendefinisikan keputusan sebagai pemilihan suatu tindakan dari dua pilihan alternatif atau lebih".

Sedangkan menurut Setiadi (2003) dalam Sangadji dan Sopiah (2013:121), "Mendefinisikan bahwa inti dari pengambilan keputusan konsumen adalah proses pengintegrasian yang mengombinasikan pengetahuan untuk mengevaluasi dua perilaku altenatif atau lebih, dan memilih salah satu di antaranya".

Dari definisi di atas dapat disimpulkan bahwa keputusan pembelian adalah tahapan yang dilakukan oleh konsumen sesuai dengan pengetahuannya dalam memilih dua alternatif atau lebih.

\section{E. Indikator Keputusan Pembelian}

Indikator keputusan pembelian merupakan keterangan atau hal-hal yang melandasi konsumen sebelum melakukan keputusan pembelian. Menurut Kotler dan Keller (2007:222), terdapat indikator dari keputusan pembelian yaitu:

1. Tujuan dalam membeli suatu produk

Dalam melakukan pembelian, konsumen akan memilih salah satu dari beberapa alternatif yang ada. Konsumen memutuskan untuk tujuan apa pembelian dilakukan, yang bergantung pada jenis produk dan $\mathrm{n}$ kebutuhannya. Kebutuhan sangat dipicu oleh rangsangan internal (kebutuhan) dan eksternal (pengaruh pengguna produk serupa sesuai kebutuhan).

2. Pemprosesan informasi untuk sampai kepemilihan merek

Keputusan pembelian konsumen berpengaruh terhadap informasi yang diterima konsumen. Proses informasi terjadi ketika konsumen mengevaluasi informasi dari perikalanan, teman, atau pengalaman sendiri dari suatu produk.

3. Kemantapan pada sebuah produk

Dalam melakukan pembelian, konsumen akan memilih satu dari beberapa alternatif yang ada. Pilihan tersebut didasarkan pada kualitas mutu, harga yang terjangkau, dan faktor-faktor lain yang dapat memantapkan keinginan konsumen untuk membeli produk tersebut.

4. Memberikan rekomendasi kepada orang lain

Dalam melakukan pembelian, jika konsumen mendapatkan manfaat yang sesuai dengan sebuah produk, mereka pasti akan merekomendasikan produk tersebut dengan orang lain. Mereka ingin orang lain juga merasakan bahwa produk tersebut sangat bagus.

5. Melakukan pembelian ulang

Kepuasan konsumen akan menggunakan sebuah produk akan menyebabkan konsumen melakukan pembelian ulang produk. Mereka merasa produk tersebut sudah sesuai

Corresponding Author: Taufik

C 2021 STIE TDN. All rights reserved 
yang mereka inginkan dan harapkan.

\section{F. Hubungan Harga Produk Terhadap Keputusan Pembelian}

Beberapa variabel di dalam pemasaran dapat menjadi faktor yang dapat mempengaruhi perilaku konsumen. Pada umumnya tidak seluruh variabel pemasaran yang ditampilkan oleh perusahaan akan dipertimbangkan oleh konsumen dalam memutuskan untuk membeli suatu produk. Oleh karena itu, penetapan harga suatu produk harus benar-benar dipikirkan secara bijak tanpa menjadi penyebab kerugian atau penurunan pendapatan perusahaan dengan melihat seberapa baik kualitas produk tersebut.

Harga dan keputusan adalah hal yang harus diperhatikan oleh pemasar sebab harga adalah bauran pemasaran yang akan menentukan langsung laba bagi perusahaan. Sedangkan keputusan pembelian adalah tindakan konsumen untuk melakukan proses transaksi pemanfaatan produk atau jasa. Hubungan antara harga dengan keputusan pembelian juga dikemukakan Menurut Tjiptono (2008:152), hubungan antara penetapan harga terhadap keputusan pembelian adalah "harga memiliki dua peranan utama dalam proses pengambilan keputusan pembelian, yaitu peranan alokasi dan peranan informasi".

Harga dan lokasi merupakan bagian dari bauran pemasaran yang dapat mempengaruhi keputusan pembelian, seperti yang dikutip oleh Kotler dan Amstrong (2001:223), "Rangsangan pemasaran (marketing stimuli) yang terdiri atas produk, tempat, harga, promosi masuk ke dalam kesadaran pembeli dan akan mempengaruhi pengambilan keputusan pembelian".

Dari uraian tersebut di atas dapat disimpulkan bahwa dengan adanya faktor lokasi dan harga dapat dijadikan sebagai bahan pertimbangan konsumen untuk mengambil keputusan membeli barang yang diinginkan.

Harga merupakan salah satu faktor penentu pembeli dalam menentukan suatu keputusan pembelian terhadap suatu produk maupun jasa. Apabila produk atau jasa yang akan dibeli tersebut merupakan kebutuhan sehari-hari seperti makanan, minuman dan kebutuhan pokok lainnya, pembeli akan sangat memperhatikan harganya meskipun harga kebutuhan pokok tersebut relatif mahal dikarenakan kurangnya kebutuhan barang tersebut di pasaran.

\section{G. Kerangka Pikir}

Kerangka pikir merupakan sebuah gambaran mengenai hubungan antar variabel yang menghubungkan satu variabel dengan variabel lainnya. Menurut Sugiyono "Kerangka berpikir merupakan model konseptual tentang bagaimana teori berhubungan dengan berbagai faktor

Corresponding Author: Taufik

C 2021 STIE TDN. All rights reserved 
yang telah diidentifikasi sebagai masalah yang penting". Sedangkan menurut Muhamad (2009:75), "Kerangka pikir adalah gambaran mengenai hubungan antar variabel dalam suatu penelitian, yang diuraikan oleh jalan pikiran menurut kerangka logis".

Selanjutnya adapun yang akan menjadi acuan sebagai kerangka pikir yang menjadi dasar pemikiran Untuk mengetahui sejauh mana pengaruh antara variabel $\mathrm{X}$ terhadap variabel $\mathrm{Y}$ akan dijelaskan menggunakan gambar kerangka pikir yang menjelaskan setidaknya arah landasan teori masingmasing variabel yang kemudian akan dimasukkan dalam analiasis regresi sederhana yang akhirnya akan mendapatkan hasil yang kemudian akan direkomendasikan kepada perusahaan. Adapun kerangka pikirnya adalah sebagai berikut.

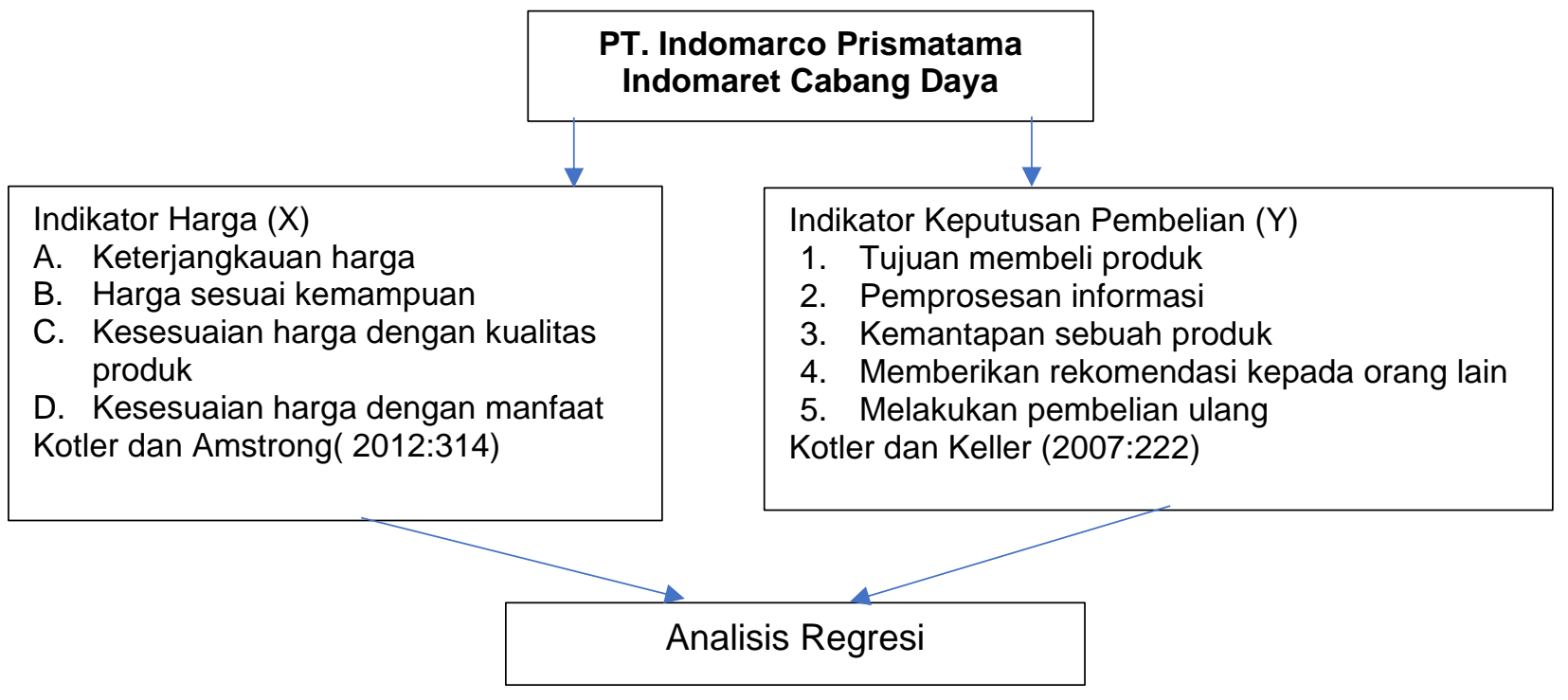

\section{H. Hipotesis}

Berdasakan latar belakang masalah, maka dirumuskan hipotesis penelitian sebagai berikut: diduga harga berpengaruh positif dan signifikan terhadap keputusan pembelian air mineral privat label pada indomaret cabang Pacerakkang Daya di Makassar

\section{METODE PENELITIAN}

\section{A. Tempat Dan Waktu Penelitian}

Adapun tempat dan waktu Penelitian ini dilakukan pada toko Indomaret Cabang Pacerakkang Daya di Jl. Pacerakkang No. 15 Daya Makassar, sedangkan waktu penelitian berlangsung selama tiga (3) bulan terhitung dari November 2020 sampai Januari 2021. 


\section{B. Jenis Dan Sumber Data}

Jenis dan sumber data yang digunakan dalam penelitian dan penulisan proposal ini adalah:

1. Jenis Data: Adapun jenis data yang digunakan pada toko Indomaret Cabang Pacerakkang Daya di Makassar adalah sebagai berikut:

a. Data kualitatif yaitu data yang diperoleh dari hasil studi perpustakaan, dan data mengenai perusahaan/instansi toko Indomaret Cabang Pacerakkang Daya di Makassar.

b. Data kuantitatif yaitu data yang berupa angka-angka pada toko Indomaret Cabang Pacerakkang Daya di Makassar.

2. Sumber Data: Sumber data diakses baik melalui perusahaan dan konsumen, baik berupa data-data yang bisa diakses langsung maupun tidak langsung. Adapun sumber data yang digunakan dalam penelitian ini adalah sebagai berikut:

a. Data primer, yaitu data yang diperoleh secara langsung dari pelanggan toko Indomaret Cabang Pacerakkang Daya.

b. Data sekunder, yaitu data yang dikumpulkan secara tidak langsung dari sumbernya, akan tetapi diperoleh dari dokumen atau jurnal (laporan-laporan) yang mempunyai kaitan dengan inti pembahasan.

\section{Populasi Dan Sampel}

\section{Populasi}

Menurut Sugiyono (2017:80), Menyatakan bahwa "Populasi adalah wilayah generalisasi yang terdiri dari objek atau subjek yang mempunyai kualitas atau karakteristik tertentu yang ditetapkan oleh peneliti untuk di pelajari dan kemudian di tarik kesimpulannya". Berdasarkan pengertian tersebut di atas, maka yang akan di tentukan untuk menjadi populasi dalam penelitian ini adalah orang-orang atau konsumen yang berbelanja terhitung mulai awal November sampai dengan akhir Januari Pada Indomaret Cabang Pacerakkang Daya di Makassar yang jumlahnya tidak terbatas.

\section{Sampel}

Sampel adalah bagian dari jumlah dan karakteristik yang di miliki oleh populasi. Bila populasi besar, dan peneliti tidak mungkin mempelajari semua yang ada pada populasi, misalnya karena keterbatasan dana dan waktu, maka penelitian dapat mengunakan sampel yang di ambil dari populasi itu (Sugiyono, 2017:81). Pemilihan jumlah sampel ini mengacu kepada pendapat ahli yaitu Gay dan Diehl (1992:146) dalam Sri Rahayu (2005:45), berpendapat bahwa semakin banyak sampel yang di ambil maka semakin representatif dan hasilnya dapat di generalisir. Namun ukuran sampel yang di terima akan sangat tergantung pada jenis penelitiannya.

a. Jika penelitiannya bersifat deskritif, maka sampel minimunya adalah $10 \%$ dari 
populasi.

b. Jika penelitiannya korelasional, sampel minimunnya adalah 30 subjektif.

c. Apabila penelitian kausal pebandingan, sampel sebanyak 30 subjek per Group.

d. Apabila penelitian eksprimental, sampel minumnya adalah 15 subjek per group.

Berdasarkan teori di atas, maka dalam penelitian ini mengunakan sampel dari populasi dari Indomaret Cabang Pacerakkang Daya Makassar sebanyak 63 orang responden.

\section{Metode Analisis Data}

Analisis data merupakan cara yang dilakukan untuk memecahkan masalah dan menguji kebenaran hipotesis yang diajukan dalam penelitian ini, maka digunakan analisis sebagai berikut :

\section{Analisis Deskriptif}

Dalam penelitian ini, penulis menggunakan analisis deskriptif, yaitu merumuskan dan menafsirkan data yang ada sehingga memberikan gambaran jelas pada perusahaan mengenai "pengaruh harga produk terhadap keputusan pembelian air mineral privat label pada toko Indomaret Cabang Pacerakkang Daya di Makassar.

Untuk mengukur masingmasing variabel digunakan instrument skala model likert. Menurut Sugiyono (2017:93), "Skala likert digunakan untuk mengukur sikap, pendapat, persepsi seseorang atau kelompok orang tentang fenomena sosial".

Dengan skala likert, maka variabel yang akan diukur menjadi indikator variabel kemudian dijadikan sebagai titik tolak ukur untuk menyusun item-item instrumen yang dapat berupa pernyataan dengan memilih salah satu jawaban diantara lima pilihan jawaban, adapun kategori dan skornya yaitu :

Tabel 2 : Pilihan jawaban kuesioner

\begin{tabular}{|c|c|}
\hline Kategori & Skor \\
\hline Sangat Baik (SB) & 5 \\
\hline Baik (B) & 4 \\
\hline Kurang Baik (KB) & 3 \\
\hline Tidak Baik (TB) & 1 \\
\hline $\begin{array}{c}\text { Sangat Tidak Baik } \\
\text { (STB) }\end{array}$ & 2 \\
\hline
\end{tabular}

Sumber : Sugiyono (2010:14)

Adapun hasil kuesioner nantinya akan disajikan dalam tabel tabulasi dan untuk menjelaskan seberapa besar persentase (\%) skor aktual terhadap variabel yang diteliti, maka akan dicari atau dihitung melalui perhitungan dibawah ini :

a. Skor Aktual

Skor aktual dalam penelitian dapat diperoleh dari hasil perhitungan jawaban seluruh responden yang telah menjawab kuesioner yang telah dibagikan. yakni sebanyak konsumen serta responden atas kuesioner yang diajukan sebanyak 10 pertanyaan terhadap setiap variabel.

Skor aktual diperoleh dari hasil 
perhitungan jumlah seluruh responden yakni jumlah keseluruhan konsumen yang berbelanja skor aktual = total skor pertanyaan diatas seluruh jawaban.

b. Skor Ideal

Skor ideal adalah untuk mendapatkan nilai Skor ideal secara keseluruhan dalam penelitian dapat diperoleh melalui perolehan prediksi nilai tertinggi dan dikalikan dengan jumlah responden yang sudah ada.

c. Presentase (\%) skor aktual

Persentase (\%) skor aktual secara keseluruhan diperoleh dari hasil perhitungan skor aktual dibagi dengan hasil perhitungan skor ideal dikalikan dengan $100 \%$.

Penentuan rentang mengacu pada skor yang digunakan yaitu banyaknya kelas interval dari angka 1 (satu) merupakan data terkecil besarnya $20 \%$, sedangkan data terbesar diperoleh dari angka 5 (lima) yang besarnya $100 \%$. Jadi rentang adalah $100 \%-20 \%$ $=80 \%$ diperoleh interval yaitu $80 \%: 5$ $=16$, sehingga penelitian untuk analisis masing-masing dari variabel dalam bentuk tabel yang di kemukakan oleh Narimawati (2007:84), tabelnya dapat kita lihat pada tabel skor tanggapan responden berikut ini:

2. Analisis Statistik

a. Analisis regresi linear sederhana

Analisis regresi linear sederhana digunakan untuk mengetahui pengaruh variabel independen (X) terhadap variabel dependen(Y). Analisis koefisien korelasi
Analisis ini digunakan hanya untuk pengaruh dua variabel yaitu satu variabel bebas dan satu variabel terikat, dalam hal ini variabel $(\mathrm{X})$ adalah harga dan variabel (Y) adalah keputusan pembelian.

Rumus regresi linear sederhana adalah sebagai berikut :

$$
Y=a+b x
$$

Dimana :

$\mathrm{X}=$ Variabel bebas (harga)

$\mathrm{Y}=$ variabel tidak bebas

(Keputusan pembelian)

$\mathrm{a}=$ Nilai intercept Konstanta

$b=$ Koefisien Regresi

Perhitungan berikutnya untuk memperoleh nilai konstanta (a) dan nilai koefisien regresi (b) maka dapat digunakan rumus sebagai berikut:

$$
\begin{gathered}
b=\frac{\mathrm{n}\left(\sum X Y\right)-(\Sigma X)(\Sigma Y)}{n\left(\Sigma X^{2}\right)-\left(\Sigma X^{2}\right)} \\
a=\frac{\Sigma Y}{n}+\frac{b(\Sigma X)}{n}
\end{gathered}
$$

Dimana :

$\mathrm{Y}=$ nilai variabel terikat (keputusan pembelian)

$\mathrm{a}=$ Intersep, yaitu titik potong garis dengan sumbu Y $\mathrm{b}=$ slope atau kemiringan garis, yaitu perubahan ratarata pada untuk setiap unit perubahan pada variabel $\mathrm{X}$ $\mathrm{X}=$ nilai variabel bebas (harga)

$\mathrm{N}=$ jumlah sampel

b. Analisis koefisien korelasi merupakan analisis statisktik yang

Corresponding Author: Taufik

(c) 2021 STIE TDN. All rights reserved 
digunakan untuk mengetahui keeratan hubungan antara variabel pengaruh harga produk terhadap keputusan pembelian air mineral merek Indomaret pada toko Indomaret Cabang Pacerakkang Daya di Makassar. Adapun rumus untuk menghitung nilai koefisien korelasi antara variabel pengaruh harga dengan variabel keputusan adalah sebagai berikut :

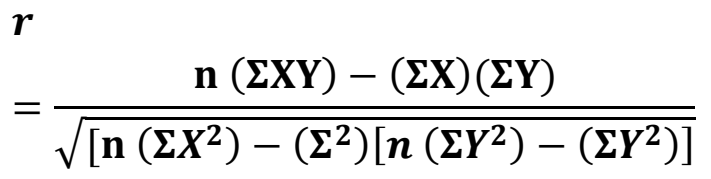

Dimana :

$\mathrm{r} \quad=$ koefisien korelasi

$\mathrm{X}=$ perubahan harga

$\mathrm{Y}=$ perubahan

keputusan pembelian

$\mathrm{n} \quad=$ jumlah sampel

c. Koefisien determinasi

Koefisien determinasi adalah angka atau indeks yang digunakan untuk mengetahui besarnya sumbangan sebuah variabel atau lebih terhadap variasi naik turunnya variabel lain, dengan rumus:

$$
K d=r^{2} X 100 \%
$$

Dimana :

$\mathrm{Kd}=$ koefisien determinasi

$\mathrm{r}^{2}=$ kuadrat koefisien

korelasi

d. Uji-t

Uji-t dikenal dengan uji parsial, yaitu untuk menguji bagaimana pengaruh masing-masing variabel bebasnya secara sendirisendiri terhadap variabel terikatnya. Selanjutnya untuk menguji hipotesis bahwa harga berpengaruh terhadap keputusan pembelian, maka dilakukan uji-t yaitu dengan membandingkan $\mathrm{t}$-hitung dengan $\mathrm{t}-$ tabel pada tingkat signifikan tertentu dengan taraf nyata $(\alpha) 0,05(5 \%)$. Berikut rumus uji $-\mathrm{t}$ adalah :

$$
t=\frac{r}{\sqrt{\frac{1-r^{2}}{n-2}}}
$$

Dimana :

$\mathrm{t}=$ nilai $\mathrm{t}-$ hitung

$r=$ nilai koefisien korelasi

$\mathrm{n}=$ jumlah data pengamatan

menentukan tingkat signifikan taraf nyata $(\alpha) 0,05(5 \%)$, nilai tabel memiliki derajat bebas (df) $=\mathrm{n}-\mathrm{k}$

Dimana :

$\mathrm{n}=$ jumlah data pengamatan

$\mathrm{k}=$ jumlah variabel, yaitu $\mathrm{X}$ dan $\mathrm{Y}$

Keterangan :

1. Apabila t-hitung > t-tabel, maka $\mathrm{H} 0$ ditolak dan menerima $\mathrm{Ha}$ artinya terdapat pengaruh signifikan antara pengaruh harga terhadap keputusan pembelian air mineral privat label merk Indomaret pada Toko Indomaret 
Cabang Pacerakkang Daya di Makassar

2. Apabila t-hitung < t-tabel, maka $\mathrm{H} 0$ diterima dan menolak $\mathrm{Ha}$ artinya tidak terdapat pengaruh signifikan antara pengaruh harga terhadap keputusan pembelian air mineral privat label merk Indomaret pada Toko Indomaret Cabang Pacerakkang Daya di Makassar.

Uji hipotesis satu arah :

a. $\mathrm{H}_{0}: \beta \leq 0$ maka tidak ada pengaruh positif antara harga dengan keputusan pembelian.

$\mathrm{H}_{\mathrm{a}}: \beta>0$ maka terdapat pengaruh positif antara harga dengan keputusanpembelian.

\section{HASIL DAN}

\section{PEMBAHASAN}

A. Karakteristik Responden
Untuk menjawab rumusan masalah dan membuktikan hipotesis yang diajukan dalam penelitian ini maka penulis melakukan pengumpulan data dengan berbagai tehnik agar mengetahui perkembangan data yang diperoleh. Responden dalam penelitian ini adalah pelanggan toko Indomaret cabang pacerakkang Daya dengan jumlah sampel 63 orang yang dapat ditinjau dari berbagai karakteristik, yaitu :

1. Karakteristik responden berdasarkan jenis kelamin Pelanggan yang membeli Air mineral privat label pada toko Indomaret cabang pacerakkang Daya terdiri dari laki-laki dan perempuan dengan perincian sebagai berikut :

Tabel 5: Persentase jenis kelamin responden

\begin{tabular}{|c|c|c|}
\hline Jenis Kelamin & Jumlah & Persentase \% \\
\hline Laki-laki & 34 & 54,0 \\
\hline Perempuan & 29 & 46,0 \\
\hline Jumlah & 63 & 100 \\
\hline
\end{tabular}

Sumber : Data diolah, 2021

Hal tersebut menunjukkan bahwa pada umumnya responden yang membeli Air mineral Privat label pada toko Indomaret cabang pacerakkang Daya didominasi oleh laki-laki.

2. Karakteristik responden berdasarkan usia

Tingkat usia sangat mempengaruhi kemampuan dan kebutuhan yang berbeda-beda serta tujuan yang berbeda-beda. adapun rinciannya dapat dilihat pada tabel berikut : 
Tabel 6: Persentase tingkat usia responden

\begin{tabular}{|c|c|c|}
\hline Tingkat usia & Jumlah & Persentase \% \\
\hline$<20$ tahun & 13 & 20,6 \\
\hline $21-30$ Tahun & 47 & 74,6 \\
\hline $31-40$ tahun & 3 & 100 \\
\hline Jumlah & 63 & \\
\hline
\end{tabular}

Sumber : Data diolah, 2021

Dari tabel di atas menunjukkan tingkat usia pada responden toko Indomaret cabang pacerakkang Daya didominasi oleh usia 21 - 30 tahun sebanyak 74,6\% dikarenakan usia tersebut paling aktif berada diluar ruangan dan sibuk beraktifitas sehingga membutuhkan komsumsi air mineral.
3. Karakteristik Responden berdasarkan tingkat pendapatan Tingkat pendapatan dari semua responden dalam penelitian ini berbeda-beda, ada yg dibawah 1 juta, 2 juta, 3 juta dan ada pula yang diatas 4 juta, sehingga dibutuhkan penggolongan setiap pendapatan untuk memudahkan mengetahui pendapatan setiap responden dalam bentuk tabel yang selengkapnya dapat dilihat sebagai berikut :

Tabel 7: Persentase tingkat pendapatan responden

\begin{tabular}{|c|c|c|}
\hline Tingkat pendapatan & Jumlah & Persentase (\%) \\
\hline <Rp. 1.000 .000 & 22 & 34.9 \\
\hline Rp.1,1 jt - Rp. 2 jt & 18 & 28.6 \\
\hline Rp. 2,1 jt - Rp. 3 jt & 9 & 14.3 \\
\hline Rp. 3,1 jt - Rp. 4 jt & 8 & 12.7 \\
\hline >Rp. 4.000.000 & 6 & 9.5 \\
\hline Jumlah & 63 & 100 \\
\hline
\end{tabular}

Sumber: Data diolah, 2021

Dari tabel di atas menunjukkan bahwa responden pada
Toko Indomaret cabang pacerakkang Daya didominasi oleh tingkat pendapatan <1 juta, hal ini disebabkan kerena harga air mineral 
privat label memang sangat terjangkau oleh kalangan manapun karena harganya yang murah.

4. Karakteristik Responden berdasarkan pekerjaan Berdasarkan pekerjaan total reponden sebanyak 63 orang

dengan berbagai latar pekerjaan masing-masing. Dengan adanya berbagai macam latar belakang

\begin{tabular}{|l|l|l|}
\hline Tingkat pendapatan & Jumlah & Persentase $(\%)$ \\
\hline Pelajar/Mahasiswa & 34 & 53.9 \\
\hline Karyawan Swasta & 22 & 34.9 \\
\hline Pegawai Negeri Sipil & 2 & 3.1 \\
\hline Wiraswasta & 5 & 7.9 \\
\hline Jumlah & 63 & 100 \\
\hline
\end{tabular}

Data diolah 2021

Dari data di atas dapat disimpulkan bahwa pekerjaan responden didominasi oleh pelajar dan mahasiswa sebab mereka yang paling banyak beraktifitas didalam dan diluar ruangan sehingga membutuhkan air mineral.

\section{B. Analisis Harga}

Dari sudut pandang pemasaran, harga merupakan satuan moneter atau ukuran lainnya yang ditukarkan agar memperolah hak Tabel 9: Tabulasi hasil kuesioner harga pekerjaan maka kebutuhan dan keinginan responden untuk membeli air mineral privat label berbeda-beda. Adapun pembagian pekerjaan semua responden yang telah bersedia melakukan pengisian kuisioner yang ada dapat dilihat pada tabel berikut ini:

Tabel 8: Persentase pekerjaan responden 
ISSN 2656-2790 (online)

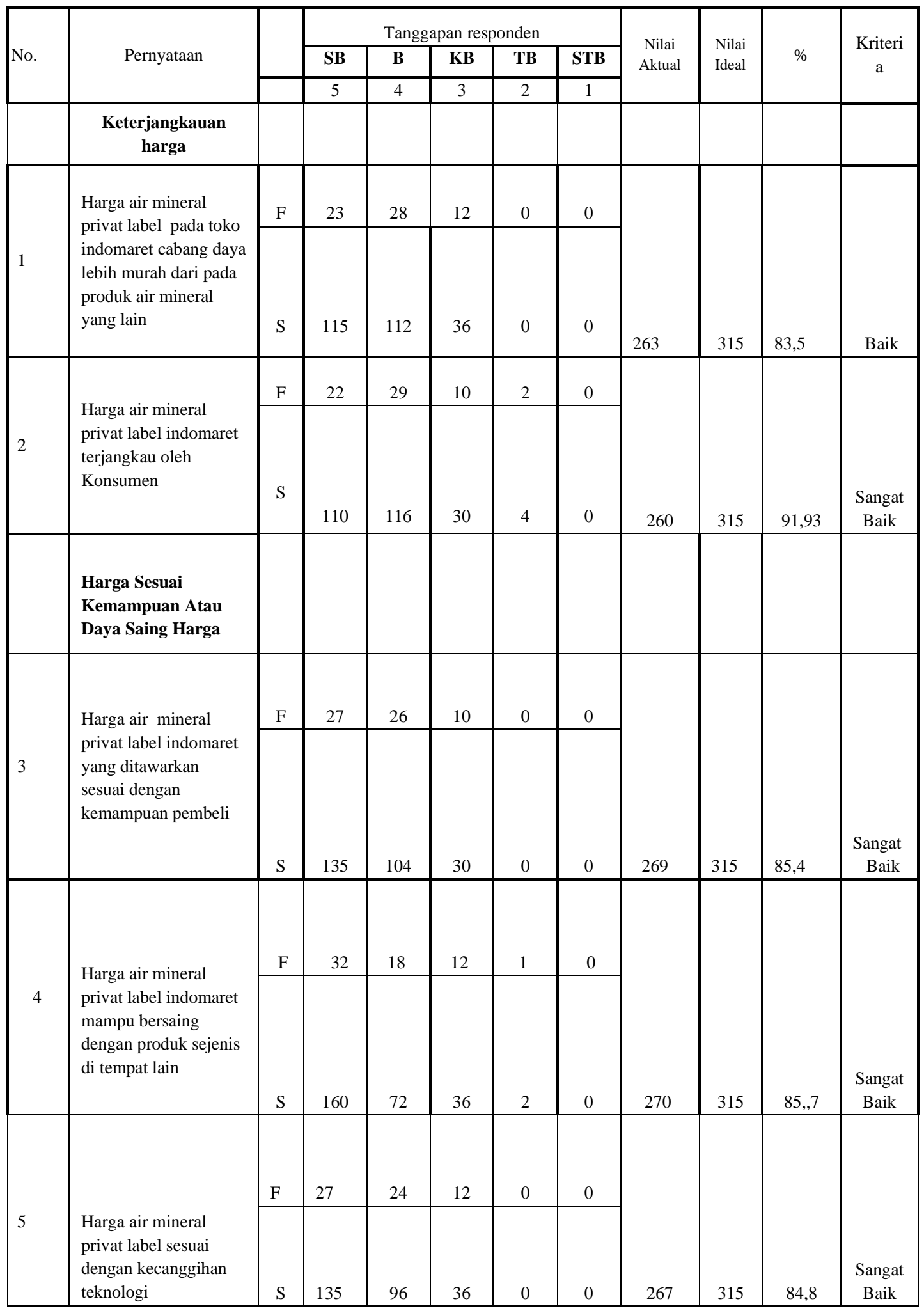




\section{Lanjutan Tabel 9}

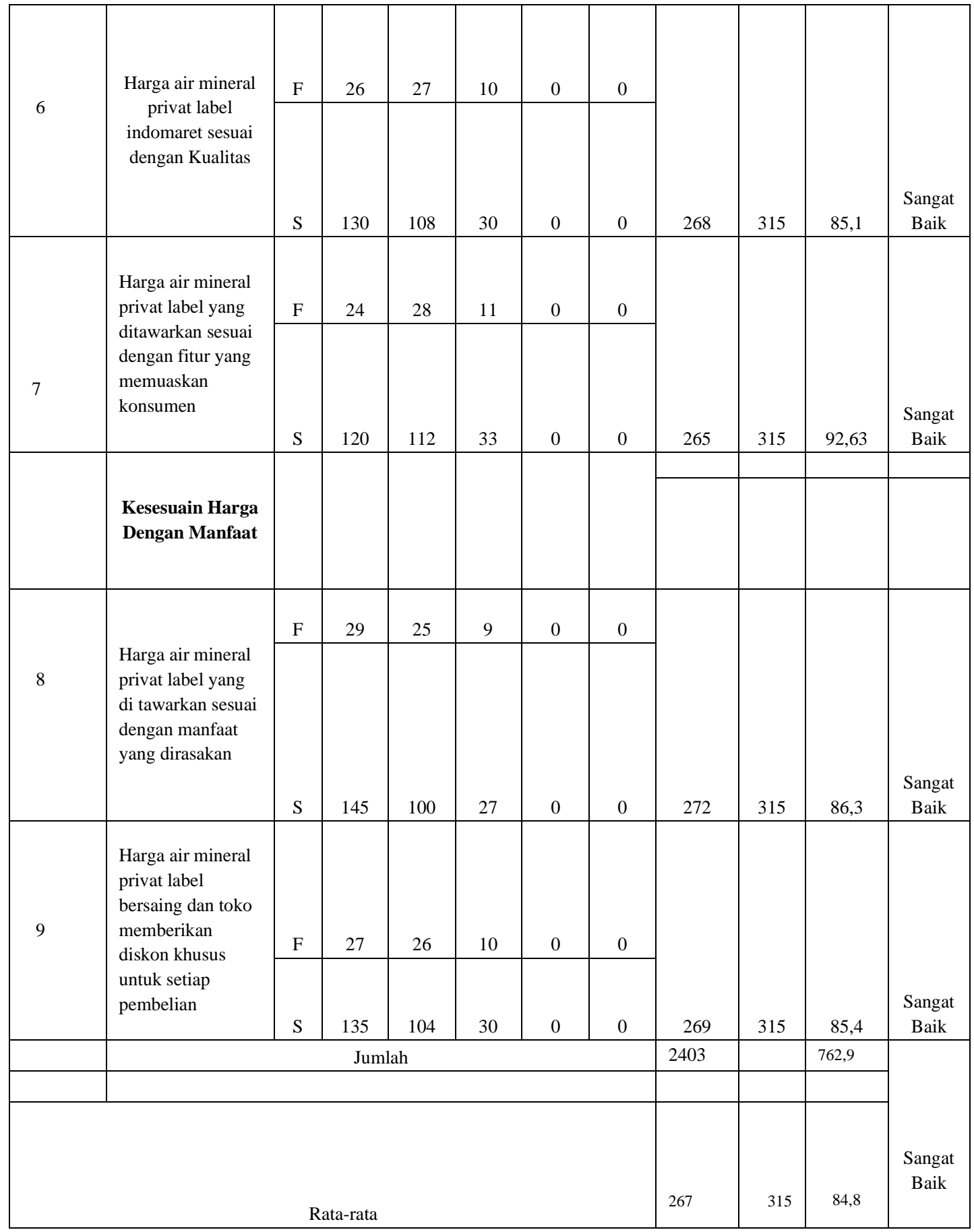

Data diolah 2021

Berdasarkan tabel di atas

Skor ideal $=5 \times 9 \times 63$

orang $=2835$

dapat diketahui:

(C) 2021 STIE TDN. All rights reserved

Corresponding Author: Taufik

174 
Skor aktual $=(237 \times 5)+$

$$
\begin{aligned}
& (231 \times 4)+(96 \times 3)+(3 \times 2) \\
& =1185+924+288+
\end{aligned}
$$
6

$=2403$

Persentase (\%) skor aktual $=\frac{2403}{2835} \times 100 \%=84,76 \%$

Berdasarkan perbandingan antara skor aktual dengan skor ideal (persentase skor aktual) diperoleh $84,76 \%$, ini menunjukkan bahwa pengaruh harga pada Toko Indomaret termasuk dalam kategori Sangat Baik, yang artinya bahwa harga berpengaruh terhadap keputusan pembelian pada toko Indomaret cabang pacerakkang Daya.

\section{Analisis Keputusan pembelian}

Keputusan membeli oleh konsumen dipengaruhi oleh banyak faktor eksternal maupun internal. Dapat kita ketahui bahwa faktor eksternal meliputi informasi pemasaran dan lingkungan sosial budaya. Sedangkan faktor internal misalnya motivasi, persepsi, sikap dan pengalaman. Keputusan pembelian sebagai variabel dependen dalam penelitian ini maka hasil kuesioner dari 63 responden dapat dilihat dari tabel berikut:

Tabel 10: Tabulasi hasil kuesioner keputusan pembelian(Y)

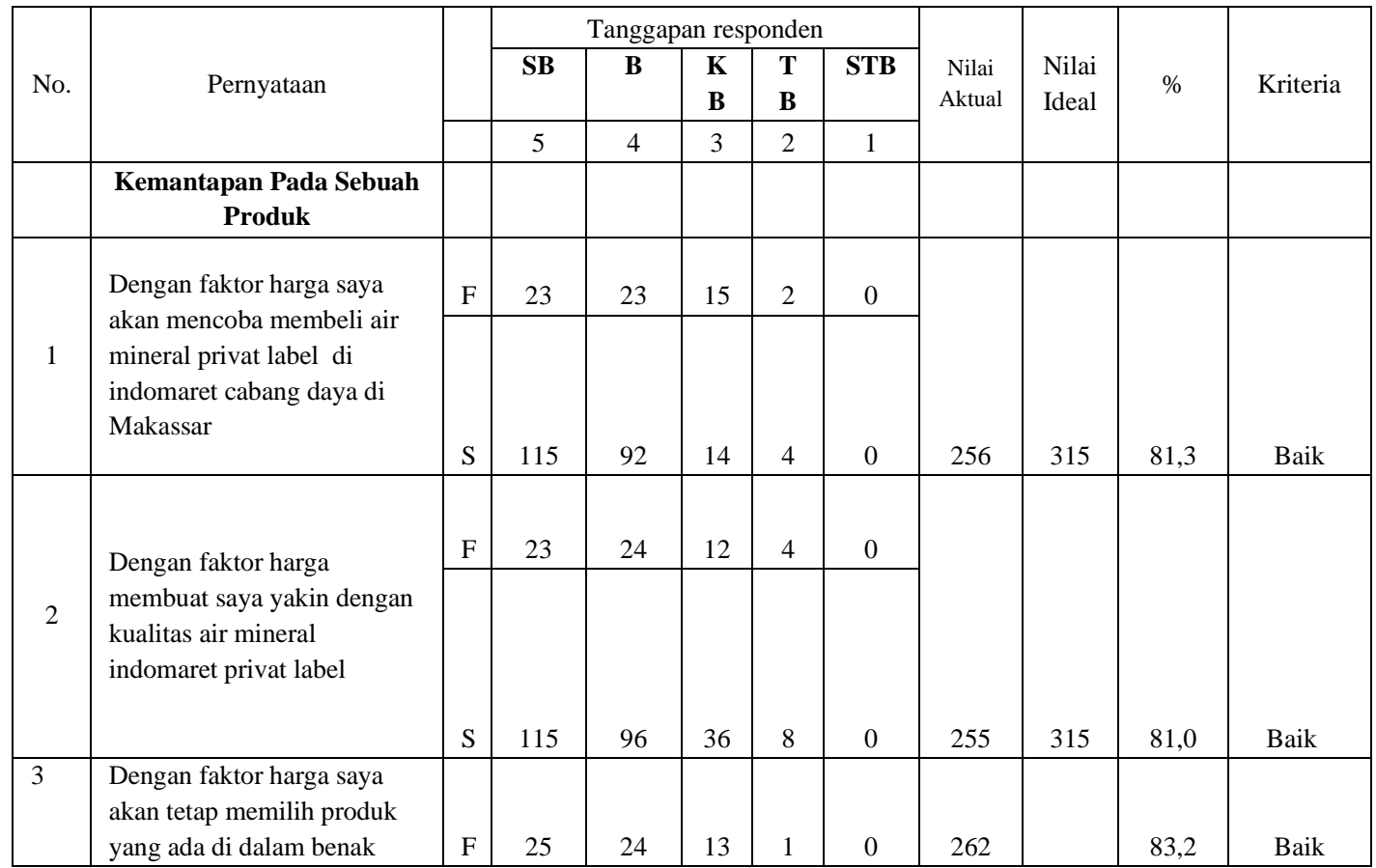

Corresponding Author: Taufik

C) 2021 STIE TDN. All rights reserved 


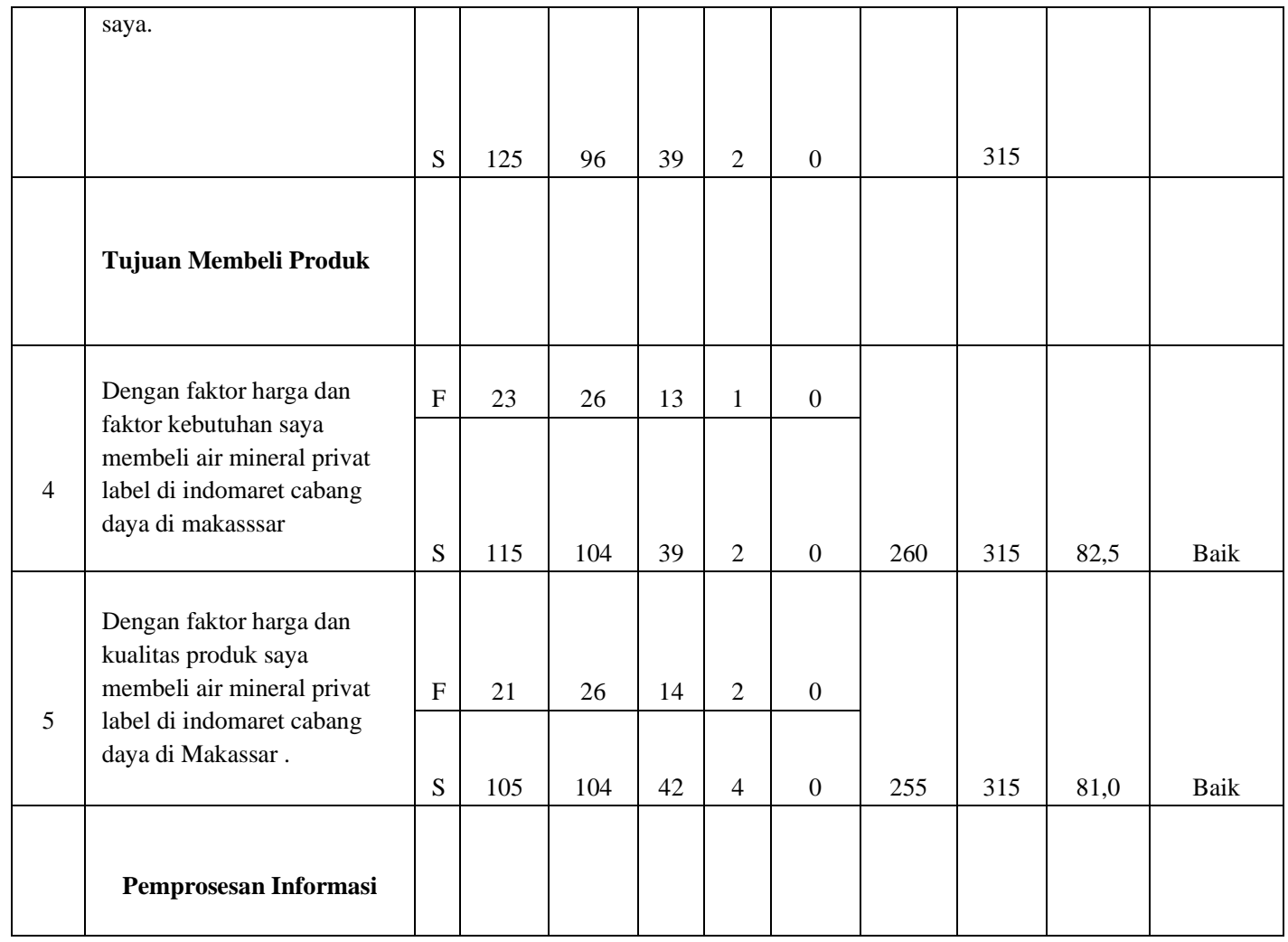

\section{Lanjutan Tabel 10}

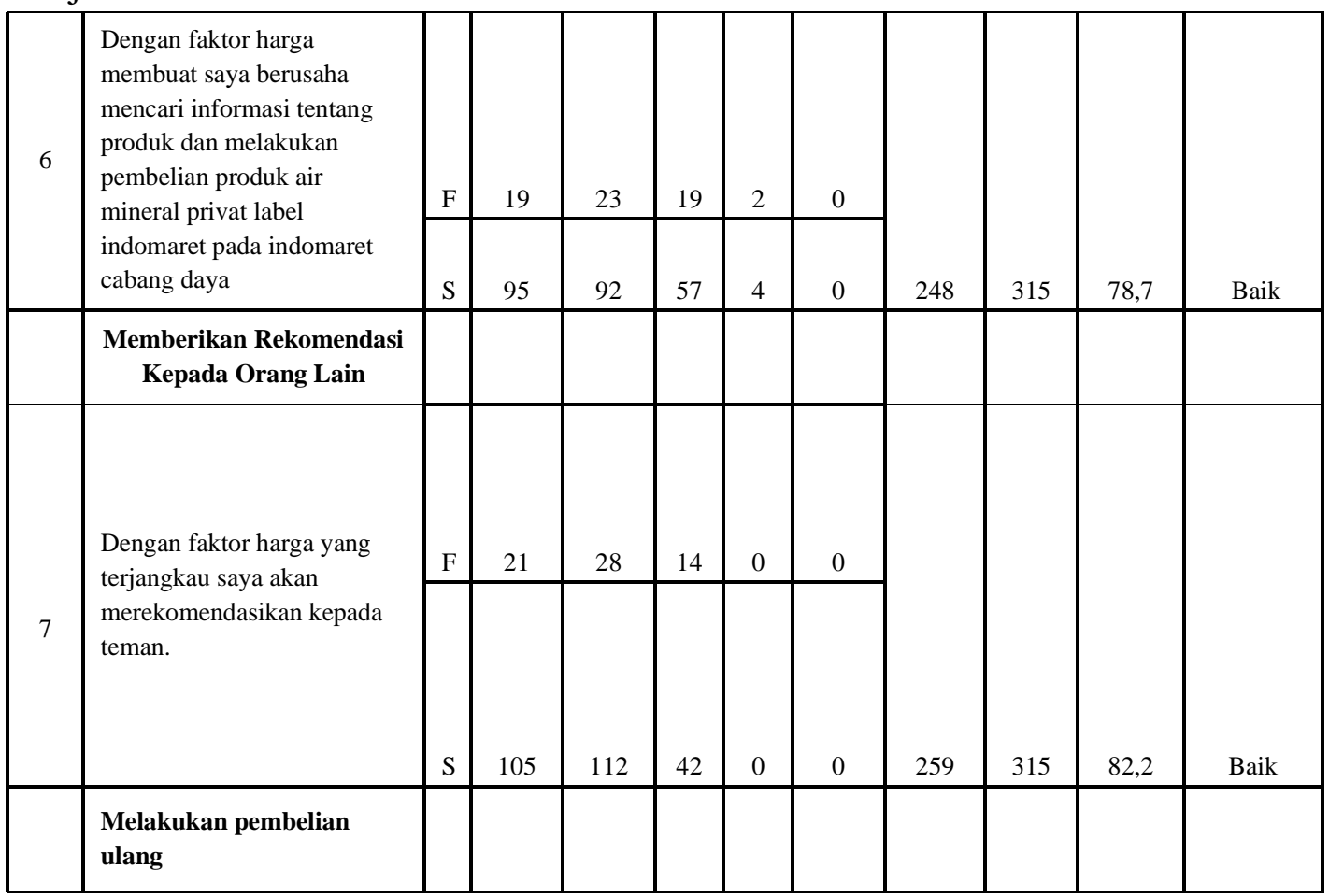




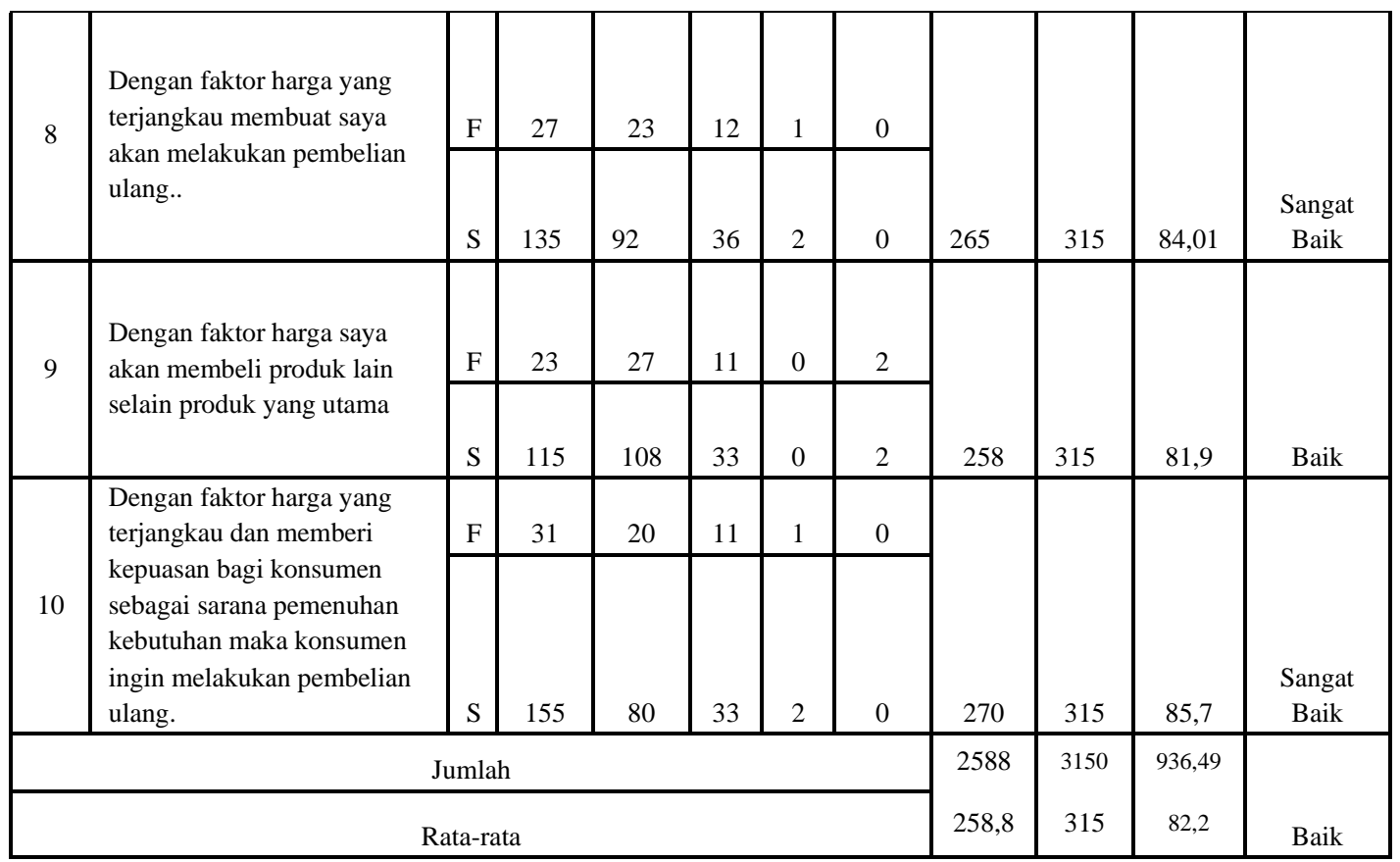

Sumber: Data diolah, 2021

Berdasarkan tabel diatas dapat diketahui:

Skor ideal $=5 \times 10 \times 63$ orang $=$ 3150.

Skor aktual $=(236 \times 5)+(244 \times 4)+$ $(134 \times 3)+(14 \times 2)+(2 \times 2)$

$$
=1180+976+402+
$$

$$
28+4
$$

$$
=2590
$$

Persentase (\%) skor aktual $=\frac{2590}{3150} \times 100 \%=82,2 \%$

Berdasarkan hasil perbandingan antara skor aktual dengan skor ideal (persentase skor aktual) diperoleh rata-rata persentase sebesar $82,2 \%$, dari data tersebut, menunjukkan bahwa harga berpengaruh terhadap keputusan pembelian air mineral privat label indomaret pada Indomaret cabang pacerakkang Daya.

\section{Analisis Kuantitatif}

Untuk mengetahui hubungan serta pengaruh harga terhadap keputusan pembelian air mineral privat label pada Indomaret cabang Pacerakkang Daya, Penulis menggunakan metode analisis berupa metode statistika yakni metode analisis regresi linear sederhana dan koefisien korelasi serta koefisien determinasi.

1. Analisis regresi linear

Analisis regresi linear sederhana adalah suatu metode pengujian untuk mengetahui pengaruh antara variabel independen (x) yaitu pengaruh harga dan dependen (y) yaitu keputusan pembelian dengan menggunakan 
ISSN 2656-2790 (online)

rumus :

Berikut data yang $\mathrm{Y}=\mathrm{a}+\mathrm{bX}$ digunakan untuk menentukan persamaan regresi linear sederhana :

Tabel 11: Skor hasil kuesioner variabel Harga dan Keputusan Pembelian

\begin{tabular}{|c|c|c|c|c|c|}
\hline $\begin{array}{c}\text { Jumlah } \\
\text { Responden }\end{array}$ & $\mathrm{X}$ & $\mathrm{Y}$ & $\mathrm{X} . \mathrm{Y}$ & $\mathrm{X}^{2}$ & $\mathrm{Y}^{2}$ \\
\hline 1 & 36 & 40 & 1440 & 1296 & 1600 \\
\hline 2 & 35 & 39 & 1365 & 1225 & 1521 \\
\hline 3 & 37 & 45 & 1665 & 1369 & 2025 \\
\hline 4 & 37 & 42 & 1554 & 1369 & 1764 \\
\hline 5 & 39 & 38 & 1482 & 1521 & 1444 \\
\hline 6 & 39 & 37 & 1443 & 1521 & 1369 \\
\hline 7 & 35 & 39 & 1365 & 1225 & 1521 \\
\hline
\end{tabular}

\begin{tabular}{|c|c|c|c|c|c|}
\hline 8 & 38 & 40 & 1520 & 1444 & 1600 \\
\hline 9 & 35 & 28 & 980 & 1225 & 784 \\
\hline 10 & 40 & 41 & 1640 & 1600 & 1681 \\
\hline 11 & 38 & 32 & 1216 & 1444 & 1024 \\
\hline 12 & 42 & 44 & 1848 & 1764 & 1936 \\
\hline 13 & 36 & 40 & 1440 & 1296 & 1600 \\
\hline 14 & 36 & 37 & 1332 & 1296 & 1369 \\
\hline 15 & 40 & 44 & 1760 & 1600 & 1936 \\
\hline 16 & 31 & 34 & 1054 & 961 & 1156 \\
\hline 17 & 44 & 50 & 2200 & 1936 & 2500 \\
\hline 18 & 41 & 42 & 1722 & 1681 & 1764 \\
\hline 19 & 42 & 48 & 2016 & 1764 & 2304 \\
\hline 20 & 39 & 43 & 1677 & 1521 & 1849 \\
\hline 21 & 38 & 42 & 1596 & 1444 & 1764 \\
\hline 22 & 36 & 47 & 1692 & 1296 & 2209 \\
\hline 23 & 37 & 41 & 1517 & 1369 & 1681 \\
\hline 24 & 37 & 42 & 1554 & 1369 & 1764 \\
\hline 25 & 36 & 38 & 1368 & 1296 & 1444 \\
\hline 26 & 38 & 42 & 1596 & 1444 & 1764 \\
\hline 27 & 40 & 39 & 1560 & 1600 & 1521 \\
\hline 28 & 31 & 34 & 1054 & 961 & 1156 \\
\hline
\end{tabular}

C 2021 STIE TDN. All rights reserved 
ISSN 2656-2790 (online)

\begin{tabular}{|c|c|c|c|c|c|}
29 & 32 & 37 & 1184 & 1024 & 1369 \\
\hline 30 & 31 & 31 & 961 & 961 & 961 \\
\hline 31 & 33 & 31 & 1023 & 1089 & 961 \\
\hline 32 & 35 & 38 & 1330 & 1225 & 1444 \\
\hline 33 & 27 & 30 & 810 & 729 & 900 \\
\hline 34 & 29 & 29 & 841 & 841 & 841 \\
\hline 35 & 31 & 34 & 1054 & 961 & 1156 \\
\hline 36 & 27 & 30 & 810 & 729 & 900 \\
\hline 37 & 35 & 39 & 1365 & 1225 & 1521 \\
\hline 38 & 31 & 34 & 1054 & 961 & 1156 \\
\hline 39 & 38 & 45 & 1710 & 1444 & 2025 \\
\hline 40 & 27 & 30 & 810 & 729 & 900 \\
\hline 41 & 45 & 50 & 2250 & 2025 & 2500 \\
\hline 42 & 43 & 48 & 2064 & 1849 & 2304 \\
\hline 43 & 37 & 40 & 1480 & 1369 & 1600 \\
\hline
\end{tabular}

\begin{tabular}{|l|l|l|l|l|l|}
\hline 44 & 38 & 38 & 1444 & 1444 & 1444 \\
\hline 45 & 45 & 50 & 2250 & 2025 & 2500 \\
\hline 46 & 41 & 45 & 1845 & 1681 & 2025 \\
\hline 47 & 45 & 50 & 2250 & 2025 & 2500 \\
\hline 48 & 45 & 50 & 2250 & 2025 & 2500 \\
\hline 49 & 45 & 50 & 2250 & 2025 & 2500 \\
\hline 50 & 44 & 50 & 2200 & 1936 & 2500 \\
\hline 51 & 45 & 50 & 2250 & 2025 & 2500 \\
\hline 52 & 45 & 50 & 2250 & 2025 & 2500 \\
\hline 53 & 39 & 41 & 1599 & 1521 & 1681 \\
\hline 54 & 43 & 42 & 1806 & 1849 & 1764 \\
\hline 55 & 38 & 39 & 1482 & 1444 & 1521 \\
\hline 56 & 32 & 38 & 1216 & 1024 & 1444 \\
\hline 57 & 45 & 48 & 2160 & 2025 & 2304 \\
\hline 58 & 45 & 46 & 2070 & 2025 & 2116 \\
\hline 59 & 45 & 50 & 2250 & 2025 & 2500 \\
\hline 60 & 42 & 45 & 1890 & 1764 & 2025 \\
\hline 61 & 45 & 50 & 2250 & 2025 & 2500 \\
\hline 62 & 44 & 45 & 1980 & 1936 & 2025 \\
\hline
\end{tabular}

C 2021 STIE TDN. All rights reserved 


\begin{tabular}{|c|c|c|c|c|c|}
\hline 63 & 38 & 37 & 1406 & 1444 & 1369 \\
\hline & $\mathrm{X}$ & $\mathrm{Y}$ & $\mathrm{X} . \mathrm{Y}$ & $\mathrm{X}^{2}$ & $\mathrm{Y}^{2}$ \\
\hline Jumlah & 2403 & 2588 & 100500 & 93291 & 108806 \\
\hline
\end{tabular}

Sumber: Data diolah, 2021

Untuk Memperolah Nilai a dan $b$, maka hasil perhitungan diatas di distribusikan ke dalam persamaan a dan b :

Untuk menentukan nilai b dapat dihitung sebagai berikut :

$$
\begin{gathered}
b=\frac{n\left(\sum X Y\right)-\left(\sum X\right)\left(\sum Y\right)}{n\left(\sum X^{2}\right)-\left(\sum X\right)^{2}} \\
b=\frac{63(100500)-(2403)(2588)}{57(93291)-(2403)^{2}} \\
b=\frac{6331500-6218964}{5317587-5774409} \\
b=\frac{112536}{456822} \\
b=0,24
\end{gathered}
$$

Untuk menentukan nilai a dapat dihitung sebagai berikut :

$$
\begin{gathered}
\mathrm{a}=\frac{\sum Y}{n}+\frac{b\left(\sum X\right)}{n} \\
\mathrm{a}=\frac{2588}{63}+\frac{0,24(2403)}{63} \\
\mathrm{a}=41,0-9,1 \\
\mathrm{a}=31,9
\end{gathered}
$$

Berdasarkan perhitungan di atas maka diperoleh persamaan regresi linear sederhana menjadi $\mathrm{Y}=$ $31,9+0,24 X$, sehingga dapat di interpretasikan sebagai berikut:

a. Nilai a $=31,9$, artinya tanpa adanya harga, keputusan pembelian pada Toko Indomaret Cabang Pacerakkang Daya tetap sebesar 31,9

b. Nilai $b=0,24$, artinya terjadi perubahan rata-rata harga air mineral privat label diharapkan dapat meningkatkan keputusan pembelian pada Toko Indomaret cabang Pacerakkang Daya sebesar 0,24 .

2. Koefisien Korelasi (r)

Selain menggunakan regresi linear sederhana, keterkaitan antara pengaruh harga dengan keputusan pembelian dapat ditentukan dengan menggunakan rumus koefisien korelasi.

Perbedaan antara regresi linear sederhana dengan metode koefisien korelasi (r) adalah, regresi linear sederhana bertujuan untuk mengetahui keterkaitan antara variabel secara umum, sedangkan koefisien korelasi (r) bertujuan untuk mengetahui seberapa kuat hubungan antara variabel $\mathrm{X}$ dengan variabel $\mathrm{Y}$.

Komponen-komponen di atas didistribusikan ke dalam persamaan koefisien korelasi (r) dengan menggunakan rumus sebagai berikut:

$=\frac{n\left(\sum X Y\right)-\left(\sum X\right)\left(\sum Y\right)}{\sqrt{\left[n\left(\sum X^{2}\right)-\left(\sum X\right)^{2}\right]\left[n\left(\sum Y^{2}\right)-\left(\sum Y\right)^{2}\right]}}$ 


$$
\begin{gathered}
r=\frac{63(100500)-(2403)(2588)}{\sqrt{\left[63(93291)-(2403)^{2}\right]\left[63(108806)-(2588)^{2}\right]}} \\
r=\frac{6331500-6218964}{\sqrt{[5877333-5774409][6854778-6697744]}} \\
r=\frac{112536}{1271324)(157034)} \\
r=0,88
\end{gathered}
$$

\section{Hasil perhitungan}

koefisien korelasi (r) di atas, dapat diketahui nilai korelasi $\mathrm{r}=0,88$. Besaran angka korelasi ini menunjukkan bahwa antara harga dengan keputusan pembelian air mineral privat label berpengaruh pada tingkat hubungan yang sangat kuat $(0,80-1,000)$.

3. Koefisien Determinasi $\left(r^{2}\right)$

$$
\text { Untuk Mengetahui }
$$

seberapa besar kemampuan harga dalam mempengaruhi keputusan pembelian, maka dapat diketahui dengan menggunakan koefisien determinasi. Biasanya koefisien determinasi adalah kuadrat dari koefisien kolerasi dan dirumuskan sebagai berikut :

$$
r^{2}=r
$$

x r

Sehingga nilai koefisien determinasi :

$$
\mathrm{r}^{2}=
$$

$0,88 \times 0,88=0,7744$

Dari $r^{2}=0,7744$ ini berarti bahwa keputusan pembelian sebesar $77,44 \%$, sedangkan sisanya sebesar
22,56\% dipengaruhi oleh faktor lain diantaranya seperti kualitas produk dan lain-lain.

4. Uji $\mathrm{t}$

Uji statistik yang digunakan adalah uji t-hitung. Uji t adalah uji hipotesis yang dilakukan dengan langkah-langkah sebagai berikut. Sebelumnya penulis menyatakan hipotesis sebagai berikut:

a. Apabila t-hitung > t-tabel, maka Ho ditolak dan menerima $\mathrm{H}_{\mathrm{a}}$ artinya terdapat pengaruh signifikan antara harga dengan keputusan pembelian air mineral privat label pada Toko Indomaret cabang Pacerakkang Daya.

b. Apabila t-hitung < t-tabel, maka Ho diterima dan menolak $\mathrm{H}_{\mathrm{a}}$ artinya tidak terdapat pengaruh signifikan antara harga dengan keputusan pembelian air mineral privat label pada Toko Indomaret Pacerakkang cabang Pacerakkang Daya.

b. $\mathrm{H}_{0}: \beta \leq 0$ maka tidak ada pengaruh positif antara harga dengan keputusan pembelian.

c. $\mathrm{H}_{\mathrm{a}}: \beta>0$ maka terdapat pengaruh positif antara harga dengan keputusan pembelian.

Selanjutnya ditentukan

Corresponding Author: Taufik

(C) 2021 STIE TDN. All rights reserved 
tingkat signifikasi pada taraf nyata $(\alpha)$ yakni sebesar $5 \quad \% \quad(0.05)$. Kemudian menentukan nilai t-tabel dengan derajat bebas menggunakan rumus:

$$
\begin{aligned}
\mathrm{df} & =\mathrm{n}-\mathrm{k} \\
\mathrm{df} & =63-2 \\
\mathrm{df} & =61
\end{aligned}
$$

Sehingga nilai t-tabel dengan uji satu arah adalah:

$$
t_{\text {tabe }} l_{0.05 ; 61}=1,67
$$

Selanjutnya menentukan nilai $t$ hitung dengan rumus sebagai berikut::

$$
\begin{aligned}
& \mathbf{t}_{\text {hitung }}=\frac{r \sqrt{n-2}}{\sqrt{1-r^{2}}} \\
& t_{\text {hitung }}=\frac{0,88 \sqrt{63-2}}{\sqrt{1-0,7744}}
\end{aligned}
$$

$$
\begin{aligned}
& \mathrm{t}_{\text {hitung }}=0.88 \times \sqrt{\frac{61}{0,2256}} \\
& \mathrm{t}_{\text {hitung }}=0.88 \times \sqrt{270,3} \\
& \mathrm{t}_{\text {hitung }}=0.88 \times 16,44 \\
& \mathrm{t}_{\text {hitung }}=14,47
\end{aligned}
$$

Nilai t-hitung diperoleh sebesar 14,47 sedangkan nilai t-tabel adalah 1,67, sehingga nilai t-hitung lebih besar nilai t-tabel $(14,47>$ 1,67) maka $\mathrm{H}_{0}$ ditolak dan $\mathrm{H}_{\mathrm{a}}$ diterima dimana terdapat pengaruh signifikan antara harga dengan keputusan pembelian air mineral privat label pada Toko Indomaret cabang Pacerakkang Daya. Adapun gambar grafik uji statistik koefisien korelasi adalah sebagai berikut:

Gambar 3: Grafik uji statistik koefisien korelasi

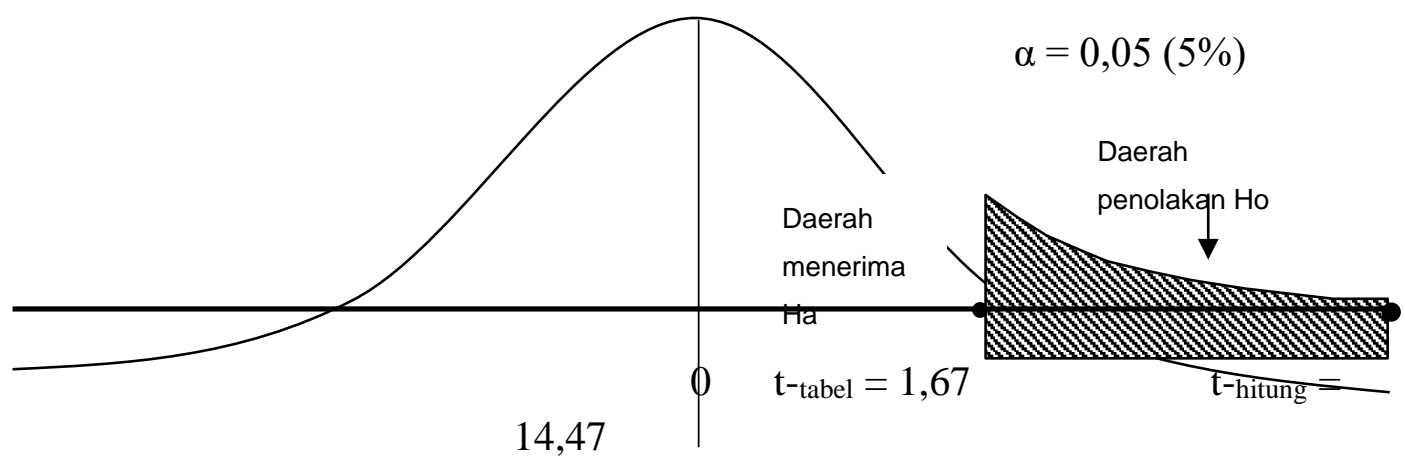

Sumber: Data diolah, 2021 
Nilai t-hitung ternyata terletak pada daerah menolak $\mathrm{H}_{0}$ dan menerima $\mathrm{H}_{\mathrm{a}}$. Ini menunjukkan terdapat cukup bukti untuk menolak $\mathrm{H}_{0}$, dan menerima $\mathrm{H}_{\mathrm{a}}$. Berdasarkan hipotesis "Diduga bahwa harga berpengaruh terhadap keputusan pembelian Air mineral privat label pada Indomaret Cabang Pacerakkang Daya" karena itu berdasarkan hasil Uji $t$ dapat disimpulkan bahwa hipotesis $\left(\mathrm{H}_{0}\right)$ ditolak dan hipotesis alternatif $\left(\mathrm{H}_{\mathrm{a}}\right)$ diterima pada taraf signifikan 0,05.

Berdasarkan hasil hipotesis di atas diperkuat dengan adanya teori yang dikemukakan oleh Kotler dan Amstrong (2001:223), “Rangsangan pemasaran (marketing stimuli) yang terdiri atas produk, tempat, harga, promosi masuk ke dalam kesadaran pembeli dan akan mempengaruhi pengambilan keputusan pembelian". Serta didukung dengan hasil penelitian terdahulu Lestari, Daslan Simanjuntak (2017). Pengaruh Produk, Harga, Distribusi Dan Promosi Terhadap Keputusan Pembelian Konsumen Di Minimarket Radja Pas Rantauprapat. Dengan Hasil uji t (parsial) produk berpengaruh positif dimana 1,922 > 1,67 , variabel harga berpengaruh positif dan signifikan 3,799>1,6. Variabel distribusi berpengaruh positif $1,752>1,67$ dan variabel promosi positif 1,752 > 1,67

\section{PENUTUP}

\section{A. Kesimpulan}

Hasil dari pembahasan yang telah terpaparkan dengan jelas pada bab sebelumnya, dapat ditarik kesimpulan bahwa dari hasil analisis perhitungan dengan menggunakan rumus analisis linear sederhana didapatkan Persamaan hasil nilai regresi sederhana yang ada, berpengaruh signifikan antara harga terhadap keputusan pembelian air mineral Indomaret privat label. Hasil analisis koefisien korelasi dimana menunjukkan bahwa pengaruh harga pada korelasi berada dalam kategori sangat kuat terhadap keputusan pembelian. Kemudian Hasil koefisien determinasi yang menunjukkan bahwa harga memiliki kemampuan untuk mempengaruhi keputusan pembelian. Hasil analisis statistik yang dilakukan melalui uji-t, dimana $\mathrm{H}_{0}$ ditolak dan menerima $\mathrm{H}_{\mathrm{a}}$. Sehingga dapat disimpulkan bahwa terdapat pengaruh atara harga dengan keputusan pembelian.

\section{B. Saran}

Berdasarkan penelitian yang telah dilakukan, penulis mencoba memberikan saran-saran yang nantinya dapat dipertimbangkan oleh pihak toko Indomaret cabang Pacerakkang Daya di Makassar, Adapun saran-saran yang penulis dapat berikan yaitu Diharapkan buat Toko Indomaret cabang Pacerakkang Daya, selain memacu laba besar mungkin dalam meningkatkan penjualan produknya perlu juga memperhatikan harga yang ditetapkan oleh kompetitor lain. Serta, jika dilihat dari hasil penelitian oleh penulis dan melihat dari tabel analisis nilai tertinggi kriteria (sangat baik) dan nilai baik perlu kiranya dipertahankan jika perlu ditingkatkan lagi sehingga ke depannya akan lebih banyak lagi calon konsumen yang terpengaruh dan kemudian melakukan keputusan pembelian pada Toko Indomaret cabang Pacerakkang Daya di Makassar. 
ISSN 2656-2790 (online)

Sekali lagi ini hanya saran yang dapat peneliti berikan, selebihnya itu otoritas serta hak dari pimpinan, untuk hal- hal yang bernilai positif dan punya pengaruh baik untuk perusahaan, tentu butuh dipertimbangkan

\section{DAFTAR PUSTAKA}

Alma, Buchari. 2018. Manajemen Pemasaran dan Pemasaran Jasa. Cetakan ke-13, Alfabeta, Bandung.

Desi Irana Dewi Lubis, Rahmat Hidayat. 2017. Pengaruh Citra Merek Dan Harga Terhadap Keputusan Pembelian Pada Sekolah Tinggi Ilmu Manajemen Sukma Medan. Jurnal Ilman, Vol. 5, No. 1, pp. 15-24, Februari 2017, ISSN 2355-1488.

Idrus, Muhammad. 2009. Metode Penelitian Ilmu Sosial, Erlangga, Yogyakarta.

Irayuliana, Jonson. 2017. Pengaruh Harga Dan Promosi Terhadap Keputusan Pembelian Pada PT. Zuvace Mondy. Jurnal Vol 2 No 7 tahun 2017.

Kotler dan Garry Amstrong. 2001. Prinsipprinsip Pemasaran, Edisi ke 12 ,Jilid 1, Erlangga, Jakarta.

921E-ISSN:2528-0570 HAL: 186-196.

Rahayu, Sri. 2005. Aplikasi SPSS Versi 12.00 Dalam Riset Pemasaran. Cv. Alfabeta, Bandung.

Sangaji, E.M Dan Sopiah. 2013. Perilaku Konsumen. CV. Andi, Yogyakarta.

Sari, Fanny Puspita dan Yuniati, Tri. 2016. Pengaruh Harga Citra Merek dan Word of Mouth terhadap Keputusan Pembelian Konsumen. Jurnal Ilmu dan Riset Manajemen: Volume 5, dan Kevin Lane Keller. 2007. Manajemen Pemasaran, Alih Bahasa Benyamin Molan, Jilid 1, Cetakan Ke 2, Indeks, Jakarta. 2009.

Manajemen Pemasaran. Edisi 13

Jilid 1. PT. Indeks, Jakarta dan Gary Amstrong. 2012. Prinsipprinsip Pemasaran Edisil3 jilid 1, Erlangga, Jakarta.

Lestari, Daslan Simanjuntak. 2017. Pengaruh Produk, Harga, Distribusi Dan Promosi Terhadap Keputusan Pembelian Konsumen Di Minimarket Radja Pas Rantauprapat. Jurnal Ecobisma Vol 4 No. 1 Jan 2017.

Malau, Harman. 2017. Manajemen Pemasaran. Cetakan ke-1, Alfabeta, Bandung.

Nur Aulia Agustina, Seno Sumowo, Bayu Wijayantini. 2018. Pengaruh Produk, Citra Merek Dan Harga Terhadap Keputusan Pembelian. Jurnal Penelitian Ipteks Vol. 3 No. 2 Juli 2018

p-ISSN:2459-9

Nomor 6, Juni 2016 ISSN : 24610593.

Sugiono . 2010. Metode Penelitian Pendidikan Pendekatan Kuantitatif, Kulaitatif Dan $R \&$ \&, $\mathrm{Cv}$. Alfa Beta, Bandung.

2014, Metode Penelitian Pendidikan Pendekatan Kuantitatif, Kulaitatif Dan $R \&$ D, $\mathrm{Cv}$. Alfa Beta, Bandung. 
ISSN 2656-2790 (online)

. 2017. Metode Penelitian

Kuantitatif, Kualitatif, $R \quad \& \quad D$, Alfabeta, Bandung.

Suryani, Tatik. 2017. Manajemen Pemasaran. Cetakan ke-1, Prenadamedia Grup, Jakarta.

Swastha, Basu Dan Irawan. 2008. Manajemen Pemasaran Modern. Edisi Kedua Cetakan Ketigabelas. Liberty Offset, Yogyakarta.

Tjiptono, Fandy. 2008. Strategi Pemasaran. Edisi 3. Yogyakarta : And dan Diana Anastasia. 2016.

Pemasaran, Esensi dan Aplikasi. Edisi 1. Andi, Yogyakarta 2019. Strategi Pemasaran, Prinsip dan Penerapan. Edisi 1. Andi, Yogyakarta.

Umi, Narimawati. 2007. Riset Manajemen Sumber Daya Manusia, Aplikasi Contoh Dan Perhitungan, Agung Media, Jakarta. 